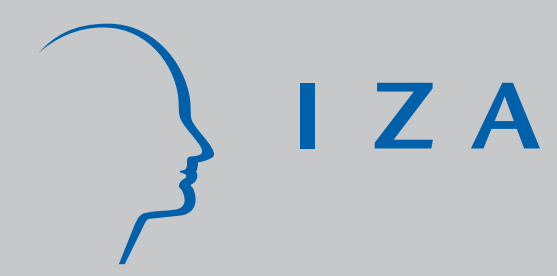

IZA DP No. 303

Social Capital and the Uncertainty Reduction of Self-Employment

Boris F. Blumberg

Gerard A. Pfann

J une 2001 


\title{
Social Capital and the Uncertainty Reduction of Self-Employment
}

\author{
Boris F. Blumberg \\ Business Investment Research Center, Maastricht University \\ Gerard A. Pfann \\ Business Investment Research Center, Maastricht University, \\ CEPR and IZA, Bonn
}

Discussion Paper No. 303 June 2001

\author{
IZA \\ P.O. Box 7240 \\ D-53072 Bonn \\ Germany \\ Tel.: +49-228-3894-0 \\ Fax: +49-228-3894-210 \\ Email: iza@iza.org
}

This Discussion Paper is issued within the framework of IZA's research area The Future of Work. Any opinions expressed here are those of the author(s) and not those of the institute. Research disseminated by IZA may include views on policy, but the institute itself takes no institutional policy positions.

The Institute for the Study of Labor (IZA) in Bonn is a local and virtual international research center and a place of communication between science, politics and business. IZA is an independent, nonprofit limited liability company (Gesellschaft mit beschränkter Haftung) supported by the Deutsche Post AG. The center is associated with the University of Bonn and offers a stimulating research environment through its research networks, research support, and visitors and doctoral programs. IZA engages in (i) original and internationally competitive research in all fields of labor economics, (ii) development of policy concepts, and (iii) dissemination of research results and concepts to the interested public. The current research program deals with (1) mobility and flexibility of labor markets, (2) internationalization of labor markets and European integration, (3) the welfare state and labor markets, (4) labor markets in transition, (5) the future of work, (6) project evaluation and (7) general labor economics.

IZA Discussion Papers often represent preliminary work and are circulated to encourage discussion. Citation of such a paper should account for its provisional character. 
IZA Discussion Paper No. 303

June 2001

\section{ABSTRACT \\ Social Capital and the Uncertainty Reduction of Self-Employment}

We study the self-employed decision and its relation to human and social capital. Human capital is necessary to acquire skills. Social capital dampens the effects of uncertainty about future income. Our data set consists of 1339 respondents from the same age group, who were interviewed three times in life in 1957, 1983 and 1993. The self-employment probability equals 155 and peaks between ages 24 and 26. Duration analysis shows that social capital is the most important resource for self-employment.

JEL Classification: J23

Keywords: Self-employment, social capital, human capital, event history

Gerard A. Pfann

Business Investment Research Center

Maastricht University

P.O. Box 616

6200 MD Maastricht

The Netherlands

Tel.: +31-43-388 3832

Fax: +31-43-388 4856

Email: G.Pfann@KE.UniMaas.NL

\footnotetext{
* We thank Norman Bradburn, Josef Brüderl, Daniel Hamermesh, Joop Hartog, and Ed Laumann for fruitful discussions. We also thank seminar participants at Maastricht University, Utrecht University, IZA / University Bonn, and the 1999 EEA conference. This research is in part subsidized by NWO (Dutch Science Foundation) under PIONIER grant number 400-10-041. The financial support is greatfully acknowledged.
} 


\section{Introduction}

The common economists' approach to explaining the transition into self-employment is based on the individual comparison of the expected income differences between self-employed work and paid labor under uncertainty (Borjas 1987; Evans \& Leighton 1989). Human capital theory (Becker 1964) describes the process of rational idiosyncratic investment behavior aimed at obtaining the skills to successfully entering the type of work one self thinks to be best at. A review of the extensive literature on the decision to become self-employed shows that the individual choice is assumed to depend almost entirely on differences in human capital and in expected lifetime earnings.

But the empirical support for such a straightforward explanation is ambiguous: human capital variables, like the level of education, working experience, or specific training, and earnings differences implemented to correct for self-selection bias are found to be rather inaccurate predictors of the choice to become selfemployed.

In this paper we argue that this inaccuracy is caused by three problems this literature suffers from. First, the net present value difference measures are uninformative due to the fact that the uncertainty surrounding each of the two types of employment choices are not the same and evolve differently over time. Second, investment in human capital provides people with skills necessary to decide which choice to make, but does not change the differences in uncertainty between the two options. Third, and most importantly, investing in social capital is an important mechanism to cushion the effect uncertainty can have on the transition into self-employment.

While the value of social capital has not been widely acknowledged in economic studies of selfemployment, sociologists have long since recognized its importance (Coleman, 1988). Social capital can reduce the effects of the uncertainty and increase the expected returns of self-employment in a way that education contributing to human capital cannot. The uncertainty faced by self-employed is inherently different than that for 
employees and evolves differently over time as well. This uncertainty difference renders a crude net present value comparison of the two decisions less informative (Pfann, 2001).

In this paper we propose a resource-based theory that allows for accumulating social capital through time as a route to self-employment. Individuals adjust their stock of social capital through investments in marriage, children, spending time at social events and so forth, thus continually changing the expected value of being selfemployed. The main benefit of the approach that we propose in this paper is how relevant factors, such as social background and personal ties, enter the self-employment decision and are integrated in a coherent theoretical framework rather than simply as ad hoc exogenous variables.

Explicitly specifying the role of social capital, applying time varying event history analysis to control for the otherwise unobserved heterogeneity, and distinguishing between self-employment that either arises from spread beds or originates from starting a new business provides plausible answers to what seems to have produced the ambiguous results found in the literature.

The structure of the paper is as follows. The next section reviews the existing literature. Section 3 discusses the idiosyncratic self-employment decision and derives hypotheses on the self-employment decision. The data used to test the hypotheses are described in section 4. Section 5 presents the outcomes of a timevarying duration analysis. Section 6 concludes.

\section{A Review of the Self-Employment Literature}

The decision to become self-employed has been investigated by various researchers with different academic backgrounds. Two types of quantitative empirical studies can be distinguished. One type of studies use explicative models based on a set of hypotheses derived from theoretical considerations about factors influencing the self-employment decisions. Other studies develop structural models explaining self-employment. Structural models rely on the rational that self-employment occurs if the expected returns of self-employment exceed those 
of paid work. Hence, after estimating earnings functions for self-employed and employees, for each individual the earning difference is calculated and used in the structural equation. An additional property of structural modeling is that the earnings functions contain a selectivity term.

Table 1 gives an overview of empirical studies on self-employment. ${ }^{1}$ For each study included in Table 1, the factors that influence the chance to become self-employed are divided into having significantly negative, significantly positive, or insignificant effects.

Here Table 1:

Overview of Empirical Studies Investigating the Self-Employment Decisions

The overall picture that emerges from the existing research on self-employment reviewed in Table 1 shows that the common economic rationalization that people will choose the activity with the highest expected (lifetime) income is not well supported by the empirical evidence. Most studies find no significant effect on income differences (Dolton \& Makepeace 1990; Rees \& Shah 1986; de Wit \& van Winden 1989). The effects of human capital from education are also not convincingly established. While general human capital seems to have little to no effect, results about more specific human capital, like work experience or specific training, are conflicting. Evans \& Leighton (1989) and de Wit \& van Winden (1989) report a negative effect of work experience, while studies of Evans \& Jovanovic (1989) and Dolton \& Makepeace (1990) find significant positive effects. No study rejects hypotheses on the positive relationship between financial capital and becoming selfemployed. But not all studies find significant effects of financial resources (Evans \& Jovanovic 1989; Gill 1988; Holtz-Eakin, Joulfaian \& Rosen 1994).

One of the most consistent and prominent factors to explain self-employment is whether one of the parents has been self-employed (see e.g. Blanchflower \& Oswald 1990; Carroll \& Mosakowski 1987; Lindh \& 
Ohlsson 1996; Taylor 1996). Dunn and Holtz-Eakin (2000) find a positive relationship between parents' wealth and the offspring's propensity for self-employment. They show that intergenerational effect result from experience rather than from financial resources. While the influence of the parents' economic activity is manifest, these studies assume intergenerational correlations result from unobserved family attributes, but they do not provide a clear vision about the reasons why this would be so. And other forms of social capital that may vary over time, such as relevant relationships, partnerships and children, are often not included in the analysis. Finally, all studies show that, other things equal, women are less likely to start their own business.

We find it rather surprising that given this evidence the common theoretical model used to determine selfemployment is so strongly biased towards expected future income streams with or without financial constraints with human capital as the most relevant factor that determines which skills are needed to become self-employed. Hardly any study focuses on the importance of social capital and its role to dampen the uncertainty that surrounds the self-employment decision.

\section{Why do People Become Self-Employed}

\section{Self-employment Decisions under Uncertainty}

Most studies explain the choice of self-employment as the discounted maximum of expected earnings associated with either self-employment or paid labor. This explanation requires that individuals perform extensive calculus to determine their expected lifetime earnings difference between self-employment and paid labor. Uncertainty and bounded rationality (Simon 1957) impede such calculus. First, as a result of technological change or non-constant information skills, it is most likely that certain businesses or employment opportunities are missing in an individual's initial choice set. Second, individuals will find it hard to obtain accurate information about the monetary value of every job offer or self-employment opportunity. Moreover, the uncertainty surrounding

$1 \quad$ We do not claim this overview to be exhaustive. 
foresights for earnings growth for wage earners is fundamentally different from that of their self-employed counterparts. The implicit assumption most studies that use a net present value (NPV) difference rule as the choice mechanism make is that the uncertainty associated with both activities is the same and constant through time. Third, the estimation of the net present value of lifetime earnings requires a long-term horizon of more than 40 years on average for young workers. In terms of real choice options, this amounts to an almost infinite uncertainty of the future development of value differences between the possibilities within the choice set, that is between being a wage earner and being self-employed. The three considerations mentioned here render the NPV calculus based on one type of uncertainty uninformative.

The different uncertainty paths that determines the value differences between various career decisions thus makes the comparison of expected lifetime incomes from self-employment and paid labor an untrustworthy guidance. Empirical evidence on income differences in the Netherlands supports the assumption of high future uncertainty. The average net income of self-employed was Euro 23400, which exceeds that of Euro 17600 for wage earners in 1993 (CBS 1995). Figure 1 presents the relation between annual income differences between self-employed and wage earners from 1959 to 1993 (CBS 1999). It shows the positive relation and its variance between current income differences and the decision of self-employment.

\section{Here Figure 1:}

Relation self-employment rate and relative income advantage of self-employed for the Netherlands 1959-1993

Individuals who believe to be unsuccessful business owners will prefer paid jobs or will have to rely on unemployment benefits if no jobs are available. On the other hand, an individual who expects to a successful entrepreneur will choose for self-employment as the most important economic activity. These idiosyncratic expectations can change over time, however, and the changes need not be exogenous. Consequently, an 
assessment of someone's specific resources needed to make the decision to become self-employed and how someone can invest in resources over time is needed to study the transition from paid labor into self-employment through time.

The expectations of success chances of self-employment are closely linked to personal, especially entrepreneurial, capabilities as well as to accessible resources and to earlier investments in relevant resources. Following Becker (1996) we distinguish two types of resources personal and social capital. ${ }^{2}$ "Personal capital includes the relevant past consumption and other personal experience that affect current and future utilities. Social capital incorporates the influence of past actions by peers and others in an individual's social network and control system." (Becker 1996: p.4). Social capital can dampen the effects of uncertainty in a way investments in human capital cannot. It is therefore considered one of the most relevant idiosyncratic resources for a person who thinks about becoming self-employed.

\section{Entrepreneurial Capabilities and Human Capital}

Penrose (1959) defined entrepreneurial capabilities and identified four qualities an entrepreneur cannot do without: (1) ambition, (2) fund raising ingenuity, (3) versatility, and (4) good judgment. In order to become successfully self-employed one may acquire these capabilities through time. These qualities are typically not taught at school. General education focuses on the accumulation of knowledge rather than on the acquisition of practical know-how. Moreover, entrepreneurial capabilities are typically not part of the vocational education curricula either. Given the observed income differences we assume that, other things equal, it is to be preferred to be selfemployed rather than an employee at some point in time. The fact that some people remain wage earners all their life signals that it may take more than a worker's lifetime to obtain sufficient resources to become self-employed.

\footnotetext{
${ }^{2}$ Becker distinguishes two types of human capital, namely personal and social capital. We - as most other authors -- use the term human capital for Becker's personal capital and treat social capital as observably different from human capital (see e.g. Coleman 1988).
} 
Vocational schooling is designed to learn professional skills, i.e. it is an investment in technical skills typical for the profession. Carpenters invest in their wood working skills, teachers invest in skills transmitting information to children, and econometricians invest time and effort in learning how to build and estimate economic models. Having such skills is important to practice one's profession, but may not be sufficient to start a business. On top of the technical skills to provide a service or produce a product, self-employment requires commercial ingenuity. We argue that people who have had an education that includes commercial elements are better equipped to become self-employed.

Hypothesis 1: $\quad$ Commercial and specific self-employment elements in educational programs shorten the time (duration) to become self-employment.

More specific forms of human capital are closely related to work experience. Over the years individuals attached to a specific profession continue to invest in specific human capital. Studies on the success of newly founded businesses indeed find a positive relationship between work experience and business success (see, e.g., Bates 1990; Brüderl, Preisendörfer \& Ziegler 1992). One expects to find a similar relationship between work experience and the decision to become self-employed. However, additional experience, or learning on the job, increases idiosyncratic productivity and thus lower the chance to become self-employed. ${ }^{3}$ But postponing the self-employment decision can also be interpreted as a decision to invest in additional skills in order to increase one's resources needed to make a future self-employment decision.

\section{Social Capital and Family Background}

Next to human capital we introduce social capital as an important resource that can help dampen the effect of uncertainty on the self-employment decision. Social capital is obtained through one's social relations and

\footnotetext{
3 At least if we do not consider transitions from employment into unemployment and parenthood.
} 
their accessible resources (for more general notions on social capital see Flap 1988; Coleman 1988, 1990; Burt 1992; Dasguptha 1999). An important attribute of social capital is that it helps cushioning the effect uncertainty can have on the expected evolvement of future earnings (Kim and Laumann, 2001). More social capital reduces the expected variance of future income streams, thus increasing the propensity to become self-employed. Granovetter (1973) introduced the distinction between strong and weak ties in his study on the influence of one's social network on the labor market success. Strong ties are contacts to family members and close friends while contacts to acquaintances and colleagues classify as weak ties. In this study we focus on an individual's most important peers: the parents, the spouse and the children. Empirical evidence suggests that strong family ties are most important for business founders, while weak ties are less relevant (Brüderl \& Preisendörfer 1998). ${ }^{4}$

Social capital is based on the resources already acquired through the social network and the access to the resources of the network ties, which include the tie's financial and human capital as well as their social capital. Research on ethnic entrepreneurship reveals for example that within the closely knitted communities of Chinese and Korean immigrants even distant family members are willing to fund a new business start-up (Bates 1997; Light \& Bonacich 1988). ${ }^{5}$ Further, the human capital present in network ties can often compliment one's own human capital or substitute the lack of it. Family members with specific human capital, for example a mother who is a lawyer or a brother that works in an accounting practice, are valuable resources. It should be noted that the knowledge and know-how nested in one's network accumulates and updates through time because the ties themselves will (re)invest in their stock of (human) capital. Finally, past interactions with social relations will equip oneself with advantageous knowledge and experience.

In this paper we focus on social capital related to that of main peers: parents, partner and children. In the personality forming adolescence phase of life parents belong to the most important social relations who transmit

$4 \quad$ It should be noted that insufficient empirical evidence for the impact of weak ties must partly ascribed to superficial measurement of weak tie social relations. 
their knowledge, capabilities and attitudes to their children. Parental self-employment experience and the parents' educational level are indicators of social background that can be influential for the self-employment decision. Selfemployed parents facilitate such a decision by transferring entrepreneurial capabilities and attitudes to their children. Furthermore, parents often serve as a role model for their children so that the children's occupational choices reflect the occupation of the parents (Blau \& Duncan 1967).

Hypothesis 2: $\quad$ Having self-employed parents shortens the offspring's time (duration) to selfemployment.

The parents' educational levels capture the transfer of more general human capital and serves also as a proxy for the amount of financial resources accessible through family ties. Thereby we assume that education is positively correlated with income and financial wealth. Higher educated parents can not only provide more financial resources but also they are more likely to transmit cultural capital and social capabilities (Di Maggio 1982; Bourdieu 1977) which are for example useful in the communication with customers and banks.

Hypothesis 3: $\quad$ Having a higher educated parent reduces the offspring's time (duration) to selfemployment.

After adolescence, when spouses step into the life of many, they can become contribute in an important way to the self-employment decision providing emotional support and labor as well as financial security. Starting businesses often suffer from low profits initially, which may result in severe liquidity constraints, that can have an impact of the household finances as well. A spouse with an own income source can ease these liquidity constraints and thereby foster the decision to become self-employed. But also non-working spouses can improve

5 In the Netherlands the government even supports such family financing. The so-called "Aunt Agathe act" offers her a tax 
the liquidity situation of a starting business, because they often step into the business as an unpaid and reliable employee especially when work mounts up (Sanders \& Nee 1996).

Hypothesis 4: $\quad$ Marriage shortens the time (duration) to self-employment.

Up to now we emphasized the supportive features of social relations. However, social ties are two sided and also create obligations, because they are based on some kind of reciprocity. Hence, from time to time social relations will make a claim on one's own resources. Such social demands can restrict the pursuit of one's own goals. Children are a special kind of social relations that will claim affection and time that cannot then be invested in building up the business. Furthermore, the larger risk is that is associated with an income from self-employment, the more problematic it will for someone being responsible for dependent children compared to someone without such responsibilities. Hence, the responsibility for children will impede the transitional step into self-employment.

Hypothesis 5: $\quad$ Having children lengthens the time (duration) to self-employment.

\section{Taking over a Family Business versus Real Founding}

A self-employed person is not necessarily an entrepreneur. Self-employment refers to a particular income generating mechanism that is different from paid labor. There are various routes to self-employment. The two most important ones are to take over the family business and the founding of entirely new business. ${ }^{6}$ Certainly, the relevance of accessibility to resources for self-employment will depend on the route followed. People who took over a family business cannot be compared to those who found an entirely new business. While real founders enter self-employment with the burden of financing the sunk start up costs, the continuation of a family business is

deduction for her income from capital borrowed to starting businesses. 
like entering self-employment with a valuable set of assets at hand. Furthermore, newly founded firms suffer from liability of newness, i.e. they face lower early survival chances because they miss stable exchange relations, do not have established a reputation yet, or must learn by doing (Hannan \& Freeman 1989; Jovanovic \& Lach 1989).

Access to financial resources through one's social network can compensate these disadvantages of newly founded firms. Here we assume that the higher education of the parents the more financial resources ae accessible. We expect that social capital associated with access to financial capital is more relevant for real founders than for self-employed who step into a spread bed. Similarly, we assume that social relations providing stable income sources are also more important for real founders who face higher levels of uncertainty and failure risks. Applying these arguments to the dimensions of social capital used here, we hypothesize that the effect of the parent's education and the effect of being married is stronger for the real founders.

Hypothesis 6: $\quad$ The role of the parents' education in the timing to become self-employed is larger for real founders.

Hypothesis 7: $\quad$ The role of marriage in the timing to become self-employed is larger for the real founder.

\section{The Data}

The hypotheses developed above are tested on a data set consisting of 1339 people. This sample is part of the North Brabant longitudinal data set which contains information about 3167 individuals who were born 1939/1940 and went to school in the Dutch province of North Brabant in 1952 (Hartog \& Pfann 1985; Jonker 1995). Figure 2 explains the structure of the data set. The gray area represents the respondents of the first survey

6 Another route not considered here is 'management buyout'. 
in 1952. Then researchers took a random sample of pupils who attended the sixth grade of primary school. 2874 individuals, represented by the gray shaded area of figure 2, provided information about their school performance and family background. In 1983 all 3167 individuals were contacted again. 2588 people responded (horizontally lined area) and were asked about their later education, labor market status, earnings, and household composition. In 1993 at the age of approximately 54 the 3167 school children of 1952 were approached for the third time. The questionnaire mailed in 1993 contained questions on the labor market status since 1983 and especially on self-employment experience. 2099 individuals answered in 1993 (vertically lined area). Due to untraceable individuals and non-response ${ }^{7} 1339$ individual were interviewed at all three points of time, i.e. in 1952, 1983 and 1993 (the checkered grey area of figure 2). 208 of these respondents have ever been self-employed (see Praag 1996 for more detailed information on the data set).

Here Figure 2:

Structure of the data set

\section{Event History Ananlysis}

Encouraged by studies of the survival of newly founded businesses (see e.g. Brüderl, Preisendörfer \& Ziegler 1992) we use event history analysis to explain the entry into self-employment. Rather than conditioning on a time independent inverse Mill's ratio, as often used in traditional probit studies discussed above to correct for self-selection bias, we model a time varying hazard function. The basic principle of hazard models is to estimate the time it takes until an event occurs given that the event did not occur earlier. The hazard model estimates the probability a person becomes self-employed to date given no transition into self-employment was made before. It

7 Taking the 1952 data as a population for the data collection in 1983 non-response is not systematic for family background and school performance (see Hartog 1989). 
thus times the spell necessary to acquire enough resources to quit ajob and become self-employed. The dependent variable is the duration between year of entry into self-employment and the year of finishing education.

The chance of becoming self-employed is related to the available human and social capital. ${ }^{8}$ Two variables serve as indicators for the general human capital: (1) EDUCATIONAL LEVEL and (2) IQ. Educational LEVEL is measured on a seven points scale. The variable IQ is an additive scale of the results of three IQ-tests that were taken while the respondents attended primary school in 1952/3. Cronbach's $\alpha$, a measure for the reliability of additive scales, for the three kinds of IQ scores is with .759 sufficiently high. Entrepreneurial human capital is measured by a bi-variate variable constructed from the kind of education. The dummy variable COMMERCIAL TRAINING is equal to one if the attended education included commercial training.

The social capital endowment takes strong ties as its dominant predictor, so that only close family ties are considered. Three ties are distinguished: (1) parents, (2) marital status, and (3) own children, of which the first one is constant and the latter two vary through time. Social background is proxied by the indicator variable SELFEMPLOYED FATHER that equals one if the respondent had a self-employed father and hence grew up in a selfemployed environment.

Having no information on the access to financial equity, initial wealth is proxied by the variable that measures the EDUCATIONAL LEVEL OFTHEFATHER. The independent variables presented above are constant for the observation time 1957 to 1993 . The acquired education of the respondent, the father's educational level and economic status are not likely to change in this period. Each respondent's value for these factors is fixed before the self-employment decision is made. This chronological order is not predetermined for the two other social capital variables MARRIED and CHILDREN. A person who is married at the second interview wave in 1983 could be married before as well as after becoming self-employed. The same holds true for having children.

\footnotetext{
Appendix 1 describes the contents of all variables.
} 
Observing that respondents have children in 1983 does not tell us anything about parenthood at the time the respondent became self-employed.

The technique of event history analysis provides the opportunity to include time varying co-variates and deal with (un-)observed heterogeneity in rather different way than the traditional static probability models of selfemployment. As the year is known that a person got married and eventually divorced and remarried again the variable MARRIED can vary over time for each respondent. It takes the value one in the years a respondent is married and the value zero otherwise. Using the birth year of respondent's children we are able to construct a time varying co-variate CHILDREN . This variable turns one in the year the first child is born and turns zero again when the youngest child becomes 16 where we assume the child is not dependent on his parents anymore. ${ }^{9}$

The control variables used in this study include most of those used in earlier empirical studies in the considered controls (see Table 1). This makes it possible to compare our results with those found by others. All our respondents were born in 1939/40, so that age is not included. We control for gender with the dummy variable FEMALE.

\section{Learning to Become Self-Employed}

In our statistical model we estimate the time it takes to become self-employed. The overall picture of Figure 2a shows a hump-shaped course of the entry rate, indicating that the chance of becoming self-employed is age dependent. Given that the respondents were born in 1939 most of them entered self-employment between ages 24 and 26 (years `63 to `65). However, if we distinguish two separate classes of self-employment, those who took over a family business and those who founded a new business, the pictures change. Respondents who took over a family business account for the large increase in entries between the ages 22 and 28 (years `61 to 
`67 in Figure 3b). The entry rate of real founders, i.e. people who started a new business, is most pronounced at the age of 24 (year `63 in Figure 3c) but dies out only very slowly over time. This suggests that taking over the family business depends on age, while founding a new business does not.

Here Figure 3:

Distribution of Entry into Self-Employment for people taking over a family business and people starting a new business

Figure 3a shows that the self-employment hazard rate is hump-shaped. This can be modeled with the flexible parametric log-logistic distrib ution (see e.g., Blossfeld, Hamerle \& Mayer 1988; Yamaguchi 1991). The hazard rate based on the log-logistic distribution of duration with time-varying covariates yields

$$
\lambda\left\langle t \mid x_{t}\right\rangle=\frac{\exp \left(x_{t} \beta\right) y t^{\gamma-1}}{\left(1+\exp \left(x_{t} \beta\right) t^{\gamma}\right)}, \gamma>0
$$

If $\gamma>1$ then the density function and the hazard rate are hump-shaped. If $0<\gamma<1$, the hazard rate is monotonically decreasing with $\mathrm{t}$, and this goes faster the closer $\gamma$ gets to 0 . If $\gamma=1$ the hazard is constant through time.

In the original data set each respondent was represented by one record. Introducing the time-dependent co-variates MARRIED and CHILDREN enlarged the number of records for respondent that married and got children before self-employment. Thus, records are nested within persons, our unit of analysis. We controlled for this respondent nesting using robust estimations of the standard error in all analyses.

\footnotetext{
${ }^{9}$ Defining 16 as the age a child is not anymore dependent on its parents is certainly a little bit arbitrary. However, changing the independence
} 


\section{Estimation Results}

Table 2 shows the results of an event history analysis for the whole sample. While the results with respect to human capital are mixed, our hypotheses about the influence of social capital on self-employment are supported. This implies that the chosen approach to explain self-employment from the perspective of utilized investments in human and social capital is fruitful. In particular, we find no effect of IQ and unexpectedly significant positive effects of the variables EDUCATIONAL LEVEL and COMMERCiAL TRAining. Thus, our hypothesis 1 is not supported. Apparently, those who obtained a higher level of education also take longer to become self-employed. Further, the hypotheses 2 to 5 about the impact of different aspects of social capital are supported. A higher educated as well as a self-employed father significantly shortens the time until selfemployment. Additionally, having a spouse before being self-employed shortens the time until starting a business. The responsibility for children under age 16 prolongs the time until one embarks on the risky adventure of selfemployment.

Here Table 2:

Estimates of the log-logistic model for entry into self-employment

\section{Dependency Between Education and Self-Employment}

The end year of one's formal education marks the point of time each respondent comes at risk. Thus, choosing for a longer education does not automatically lengthen the time until self-employment. However, by taking the end of education as the earliest possible moment to become self-employed, we implicitly assume that the choice to continue education is independent from the choice to become self-employed. This assumption is problematic. Individuals aiming to become self-employed may continue education in order to obtain useful knowhow for starting a business. Other individuals may leave school earlier because they have the opportunity to take

\footnotetext{
year between 16 and 21 did not alter the results.
} 
over a family business. The possible dependency between the choice for self-employment and the choice for the aspired education level introduces endogeneity. To account for possible endogeneity bias we split our sample $\mathrm{N}$ and analyzed the sub-sample of people with a low educational level $\mathrm{N}_{\text {low }}$ separately from people with a high educational level $\mathrm{N}_{\text {high }}$.

Here Figure 4:

Graph of the Nelson-Aalen cumulative Hazard Function for the total sample and for the two educational levels low and high.

Figure 4 shows the Nelson-Aalen cumulative hazard function for all respondents and for the two subsamples. This function plots cumulative rate of becoming self-employed against the analysis time, i.e. the entry year into self-employment minus the end year of the education. Self-employment occurs slightly more often among the group of higher educated people. Especially at later ages higher educated people continue to become self-employed. Table 3 summarizes the analyses of event history models estimating the time it takes to become self-employed for the two sub-samples $\mathrm{N}_{\text {low }}$ and $\mathrm{N}_{\text {high }}$. Before the results are discussed in detail, we test if the estimates differ in the two sub-samples by comparing the log likelihood for the whole sample with the sum of the $\log$ likelihood of the two sub-samples. A chi-squared test reveals that the two sub-samples for different educational levels do differ significantly in their estimates $\left.\chi_{\mathrm{df}=9}^{2}=24,90\right)$. The models presented in Table 3 confirm the overall picture we obtained from the overall analysis in Table 2. Comparing the two models of Table 3 it can be stated that the observed differences between the sub-samples are mainly caused by different magnitudes of the effects. The direction of all effects is in both sub-samples the same but all are larger in subsample $\mathrm{N}_{\text {low }}$. This suggests that other forms of capital, especially social capital, become more important when human capital is lacking. 
Here Table 3:

Estimates of the log-logistic model for entry into self-employment for the two sub-samples $\mathrm{N}_{\text {low }}$ and $\mathrm{N}_{\text {high }}$.

In Table 3 we find no support for our hypotheses concerning specific human capital. In the sub-sample $\mathrm{N}_{\text {low }}$, the variable COMMERCIAL TRAINING is even significantly positive. All coefficients associated with social capital have the expected directions and are significant except for the variable MARRIED in the sub-sample $\mathrm{N}_{\text {high }}$.

\section{Spread Beds versus Real Founders}

The different distributions of entry over time presented in Figure 3 suggest that the decision process differs between people taking over a family business and real founders. We redid the analyses for these two groups separately. Figure 5 shows the course of the Nelson-Aalen hazard functions for the two sub-samples. For short analysis times both functions take a parallel course with slightly higher hazard rates for the spread bed group..$^{10}$ The picture changes for respondents who took longer to become self-employed after their education. Taking over a family does not occur and all entries into self-employment are start-ups of new businesses.

\section{Here Figure 5:}

Graph of the Nelson-Aalen cumulative Hazard Function for self-employed who stepped in a spread bed and who founded a new business.

Table 4 reports the outcomes. The first column reveals the results for the real founders that are based on a subsample consisting of all people who have never been self-employed and the people who founded a new business. The second column gives the result of an analysis based on the people who stepped into a spread bed and again 
all the people who never have been self-employed. Strictly speaking, this sample should only contain respondents who had the chance to step into a spread bed. However, we do not have information about which respondents could have taken over a family business if they have wanted. One possible indicator could be the variable SELFEMPLOYED FATHER. Limiting the analysis on respondents with a self-employed father does not result in remarkable changes of the direction and significance of the coefficients. Further, it should be noted that $17,5 \%$ of our respondents did not have a self-employed father and still took over a family business probably from another family member, like e.g. the parents in law.

For real founders we cannot reject the hypothesis that $\gamma$ is equal to 1 . This implies that the hazard rate for real founders is constant through time. However, the hazard rate for the self-employed taking over the family business is clearly hump shaped with an estimate of $\gamma$ significantly larger than 1.

Analogous to the analyses in Table 3 we performed the analyses for the real founders and the spread bed also separately for respondents with a low and a high educational level. The comparison of the respective log likelihood values resulted in a significant $\chi_{\mathrm{df}=9}^{2}=29,22$ for the analysis "spread beds" and an insignificant $?_{\mathrm{df}=9}^{2}=12,84$ for the real founders. Similar to the analysis of the whole sample the effects in the two educational sub-samples differ only in the magnitude but not in the sign (results not reported here).

The separate analyses of the self-employment decision reveals clear differences between the two groups. General and more specific human capital does influence the decision to take over a family business, but has no effect on founding a new business. Surprisingly, both forms of human capital delay the decision to take over the family business, even though we controlled for delays caused by attaining higher education.

Here Table 4:

Separate estimates of the log-logistic model for entry into self-employment real founders and people who stepped in a spread bed. 
We argued that access to family resources is especially important for the real founders. They begin from scratch and have a strong need for information and start up capital. The variable EDUCATIONAL LEVEL FATHER is significant for the group 'real founders' and not significant for the group 'spread bed'. This supports hypothesis 6. Further, we expected that having a spouse is more important for real founders than for self-employed who continued a family business due to the higher uncertainty they face. However, the coefficient of the variable MARRIED is positive and significant for the group "spread bed" and insignificant for the group "real founders". Interestingly, having a partner has only a positive impact for taking over a family business. This suggests that in our data set support of a spouse is only important for spread bed self-employed thus rejecting hypotheses 7 .

\section{Does Social Capital Reduce Uncertainty?}

The effects on the self-employment hazard are negative and significant for spread beds as well real founders. Having a self-employed father increases the propensity to become self-employed and shortens the route into self-employment for both groups. This takes away the concern that the higher propensity of an offspring with self-employed parents is only caused by inheritance and not by entrepreneurial learning through one's parents.

The effect of a self-employed father as well as the effect of being married is larger for low-educated people. The effect of having children reduces the self-employment hazard and this reduction is largest for low educated people. We interpret these results as a strong empirical support of the idea that social capital is especially important for those who face large future income uncertainties. It is well known that the income uncertainty faced by low educated people is much larger than for their highly educated counterparts. 
The effect of a self-employed father is larger when self-employment arises from spread beds. This can be interpreted in the following way. The father's experience as a business owner is of great value. It comes with important knowledge but more importantly with a specialized network of relevant contacts to make this particular self-employment decision less uncertain and thus more likely. The result for marriage is more difficult to explain in terms of differences in uncertainty. We expect that the difference of the marriage effect on the two routes into self-employment is related to the behavioral differences between the two: spread bed self-employment is hump shaped and peaks at about the same time as most marriage decisions are being taken. The hazard of founding a new business is constant through time and seems less dependent on the decision either or when to get married.

Summarizing, the social capital approach to explain self-employment is successful in explaining selfemployment decisions. The theoretical framework that determines the role of social capital to dampen the uncertainty inherent to its decision produced plausible hypotheses about the effects social capital variables would have on the decision to become self-employed. These hypotheses were confirmed by the empirical analysis. Moreover, the concept of social capital, the notio $n$ of time-varying propensities, and the heterogeneity between self-employed taking over the family business or started their own company are helpful in clarifying the seemingly contradictory findings found in the existing empirical literature. The use of time varying covariates also sheds light on the effects of getting married and having children.

\section{Conclusions}

We analyzed the decision to entry into self-employment from the perspective of learning over time about the reducing uncertainty surrounding the unemployment decision and about skills needed to become selfemployed. An individual's human and social capital determines the duration to change from a state of a wage earner (the risk group) into the state of self-employment. Our analysis reveals cle ar differences between people who took over an existing family business and people who founded a new firm. While the founding rate of new 
business does hardly vary with age, taking over a family business peaks at 5 to 8 years of work experience, i.e. after having formal schooling. While starting from scratch averages at the learning time of 15 years after schooling but its distribution is much more widely spread. The standard deviation of the mean time until self-employment is 10.4 for persons starting from scratch compared to 6.8 for those who step in a spread bed. Future research on self-employment should distinguish between the different roads to self-employment, and should acknowledge the important and different role social capital plays between the two possibilities.

We tested hypotheses about the influence of human and social capital on the learning time to become self-employed using a data set that is unique in terms of composition and the duration time covered. Compared to other data sources it's richness of relevant time-varying variables allowed us to identify the biases of heterogeneity, especially through variables related to social capital. However, questions may be raised about the construct validity of our measurement. For example, our results concerning the influence of human capital are mixed like in other studies. The indicator for entrepreneurial human capital is certainly only a first step in the assessment. Deeper insights into what determines entrepreneurial human capital precisely would ertainly be valuable.

We introduced social capital as an additional capital resource determining the learning time to become self-employed. It is shown that family support shortens the learning time considerably. Friends as more distant social relations could be important too, for example by providing information on new business opportunities. Social capital arising from such weaker ties was not considered here, but seems a promising extension of this analysis. 


\section{$\underline{\text { References }}$}

Bates, Timothy (1990) "Entreprene ur Human Capital Inputs and Small Business Longevity." The Review of Economics and Statistics 72, 551-559.

Bates, Timothy (1997) Race, Self-Employment and Upward Mobility. Baltimore: John Hopkins University Press.

Becker, Gary S. (1964/1993) Human Capital. A Theoretical and Empirical Analysis with Special Reference to Education. $3^{\text {rd }}$ edition. Chicago: University of Chicago Press.

Becker, Gary S. (1996) Accounting for Tastes. Cambridge: Harvard University Press.

Blanchflower, David G. and Andrew J. Oswald (1998) "What Makes an Entrepreneur?" Journal of Labor Economics 16, 26-60.

Blau, Peter M. and O.D. Duncan (1967) The American Occupational Structure. New York: Wiley.

Blossfeld, Hans-Peter, Alfred Hamerle and Karl Ulrich Mayer (1989) Event History Analysis. Statistical Theory and Application in the Social Science. Hillsdale: Lawrence Erlbaum.

Borjas, George J. (1987) "Self-Selection and the Earnings of Immigrants". American Economic Review 77, 531-53.

Borjas, George J. and Stephen G. Bronars (1989) "Consumer Discrimination and Self-Employment. " Journal of Political Economy 97, 581-605.

Bourdieu, Pierre (1977) Reproduction in Education, Society and Culture. London: Sage.

Brüderl, Josef; Peter Preisendörfer and Rolf Ziegler (1992) "Survival Chances of Newly Founded Business Organizations." American Sociological Review 57, 227-242.

Brüderl, Josef and Peter Preisendörfer (1998) "Network Support and the Success of Newly Founded Businesses." Small Business Economics 10, 213-225.

Burt, Ronald S. (1992) Structural Holes. The Social Structure of Competition. Cambridge: Harvard University Press.

Carroll, Glenn R. and Elaine Mosakowski (1987) "The Career Dynamics of Self-Employed." Administrative Science Quarterly 32, 570-589.

CBS (1995) Jaarboek inkomen en consumptie 1995. Den Haag: SDU.

CBS (1999) Tijdreeksen arbeid en sociale zekerheid. Voorburg: CBS. 
Coleman, James S. (1988) "Social Capital in the Creation of Human Capital." American Journal of Sociology 94, S95-S120.

Dasgupta, Partha (1999) Economic Progress and the Idea of Social Capital. Forthcoming.

Di Maggio, Paul (1982) "Cultural Capital and School Success. The Importance of Status Culture Participation on the Grades of U.S. High School Students." American Sociological Review 47, 189-201.

Dolton, P.J. and G.H. Makepeace (1990) "Self-Employment Among Graduates." Bulletin of Economic Research 42, 35-53.

Dunn, T. and D. Holtz-Eakin (2000), "Financial Capital, Human Capital, and the Transition to Self-Employment: Evidence from Intergenerational Links.” Journal of Labor Economics 18, 282-305.

Evans, David S. and Boyan Jovanovic (1989) "An Estimated Model of Entrepreneurial Choice under Liquidity Constraints." Journal of Political Economy97, 808-827.

Evans, David S. and Linda S. Leighton (1989) "Some Empirical Aspects of Entrepreneurship". American Economic Review 79, 519-35.

Flap, Henk D. (1988) Conflict, Violence, and Loyalty. Bern: Peter Lang.

Gill, Andrew M. (1988) "Choice of Employment Status and the Wages of Employees and the Self-Employed. Some further Evidence". Journal of Applied Econometrics 3, 229-234.

Granovetter, Mark S. (1973) "The Strength of Weak Ties." American Journal of Sociology 78, 1360-1380.

Hannan, Michael T. and John Freeman (1989) Organizational Ecology. Cambridge: Harvard University Press. Hartog, Joop (1989) "Survey Non-response in Relation to Ability and Family Background. Structure and Effects on Estimated Earning Functions" Applied Economics 21, 387-95.

Hartog, Joop and Gerard A. Pfann (1985) "Vervolgonderzoek Noordbrabantse Zesdeklassers" (Continued Research North Brabant Sixth Graders), University of Amsterdam.

Holtz-Eakin, Douglas, David Joulfaian and Harvey S. Rosen (1994a) "Entrepreneurial Decisions and Liquidity Constraints." RAND Journal of Economics 25, 334-347.

Holtz-Eakin, Douglas, David Joulfaian and Harvey S. Rosen (1994b) "Sticking it Out: Entrepreneurial Survival and Liquidity Constraints." Journal of Political Economy 102, 53-75.

Jonker, Nicole (1995) Vervolgonderzoek Noord Brabantse Zesdeklassers Codeboek (Continued Research Proje ct Sixth Formers North Brabant Codebook), mimeo University of Amsterdam.

Jovanovic, Boyan and Saul Lach (1989) "Entry, Exit, and Diffusion with Learning by Doing." American Economic Review 79, 690-699. 
Kim, Harris H. and Edward O. Laumann (2001) "Social Capital, Embedded Status, and the Endorsement Effect; Income Stratification among Chicago Lawyers, 1995.” University of Chicago.

Lentz, Bernard F. and David N. Laband (1990) "Entrepreneurial Success and Occupational Inheritance among Proprietors". Canadian Journal of Economics 23, 563-579.

Light, Ivan and Edna Bonacich (1988) Immigrant Entrepreneurs: Koreans in Los Angeles, 1965-1982. Berkeley: University of California Press.

Lindh, Thomas and Henry Ohlsson (1996) "Self-Employment and Windfall Gains. Evidence from the Swedish Lottery". The Economic Journal 106, 1515-1526.

Penrose, Edith (1959) The Theory of the Growth of the Firm. $3^{\text {rd }}$ edition (1995). Oxford: Oxford University Press.

Pfann, Gerard A. (2001) “Options to Quit”. Economics Letters 70, 259-265.

Praag, Mirjam van (1996) Determinants of Successful Entrepreneurship. Amsterdam: Thesis.

Sanders, Jimy M. and Victor Nee (1996) "Immigrant Self-Employment: The Family Social Capital and the Value of Human Capital". American Sociological Review 61, 231-249.

Simon, Herbert A. (1957) Models of Man. New York: Wiley.

Rees, Hedley and Anup Shah (1986) "An Empirical Analysis of Self-Employment in the UK." Journal of Applied Economics 1, 95-108.

Taylor, Mark P. (1996) "Earnings, Independence or Unemployment. Why become self-employed?" Oxford Bulletin of Economics and Statistics 58, 253-266.

Wit, Gerrit de and Frans A. van Winden (1989) "An Empricial Analysis of Self-Employment in the Netherlands." Small Business Economics 1, 263-272.

Yamaguchi, Kazuo (1991) Event History Analysis. Newbury Park: Sage. 


\section{Table 1}

Survey of Empirical Studies Investigating the Self-Employment Decisions

\begin{tabular}{|c|c|c|c|}
\hline & negative effect & no effect & positive effect ${ }^{\mathrm{a}}$ \\
\hline Income difference & & $\begin{array}{l}\text { Dolton \& Makepeace (1990) } \\
\text { De Wit \& van Winden (1989) } \\
\text { Rees \& Shah (1986) } \\
\end{array}$ & $\begin{array}{l}\text { Taylor (1996) } \\
\text { Gill (1988) }\end{array}$ \\
\hline \multicolumn{4}{|l|}{ Human Capital } \\
\hline Education [general] & & $\begin{array}{l}\text { Taylor (1996) } \\
\text { Dolton \& Makepeace (1990) } \\
\text { Borjas \& Bronars (1989) } \\
\text { De Wit \& van Winden (1989) } \\
\text { Evans \& Jovanovic (1989) } \\
\text { Evans \& Leighton (1989) } \\
\text { Gill (1988) } \\
\text { Carroll \& Mosakowski (1987) }\end{array}$ & Rees \& Shah (1986) \\
\hline Education [occupational] & de Wit \& van Winden (1989) & Carroll \& Mosakowski (1987) & \\
\hline Work experience & $\begin{array}{l}\text { Evans \& Leighton (1989) } \\
\text { De Wit \& van Winden (1989) }\end{array}$ & Carroll \& Mosakowski (1987) & $\begin{array}{l}\text { Dolton \& Makepeace (1990) } \\
\text { Evans \& Jovanovic (1989) }\end{array}$ \\
\hline \multicolumn{4}{|l|}{ Financial Capital } \\
\hline Assets & & $\begin{array}{l}\text { Holtz-Eakin, Joulfaian \& Rosen (1994) } \\
\text { Evans \& Jovanovic (1989) } \\
\text { Gill (1988) }\end{array}$ & $\begin{array}{l}\text { Dunn \& Holtz-Eakin (2000) } \\
\text { Lindh \& Ohlsson (1996) } \\
\text { Taylor (1996) } \\
\text { Evans \& Leighton (1989) }\end{array}$ \\
\hline Inheritance & & & $\begin{array}{l}\text { Lindh \& Ohlsson (1996) } \\
\text { Holtz-Eakin, Joulfaian \& Rosen (1994) } \\
\text { Blanchflower \& Oswald (1990) }\end{array}$ \\
\hline
\end{tabular}

(continued on next page) 


\section{Table 1 (continued)}

Survey of Empirical Studies Investigating the Self-Employment Decisions

\begin{tabular}{|c|c|c|c|}
\hline & negative effect & no effect & positive effect ${ }^{\mathrm{a}}$ \\
\hline \multicolumn{4}{|l|}{ Social Capital } \\
\hline \multirow[t]{6}{*}{ Self-employed parents } & & & Dunn \& Holtz-Eakin (2000) \\
\hline & & & Lindh \& Ohlsson (1996) \\
\hline & & & Taylor (1996) \\
\hline & & & Blanchflower \& Oswald (1990) \\
\hline & & & De Wit \& van Winden (1989) \\
\hline & & & Carroll \& Mosakowski (1987) \\
\hline \multirow[t]{6}{*}{ Marriage } & Evans \& Jovanovic (1989) & Holtz-Eakin, Joulfaian \& Rosen & Lindh \& Ohlsson (1996) \\
\hline & Evans \& Leighton (1989) & $(1994)$ & Taylor (1996) \\
\hline & Gill (1988) & Dolton \& Makepeace (1990) & \\
\hline & & Borjas \& Bronars (1989) & \\
\hline & & De Wit \& van Winden (1989) & \\
\hline & & Rees \& Shah (1986) & \\
\hline \multirow[t]{3}{*}{ Children } & Holtz-Eakin, Joulfaian \& Rosen (1994) & Taylor (1996) & Dolton \& Makepeace (1990) \\
\hline & Gill(1988) & De Wit \& van Winden (1989) & \\
\hline & & Rees \& Shah (1986) & \\
\hline \multicolumn{4}{|l|}{ Controls } \\
\hline \multirow[t]{4}{*}{ Age } & & Taylor (1996) & Holtz-Eakin, Joulfaian \& Rosen (1994) \\
\hline & & & Dolton \& Makepeace (1990) \\
\hline & & & Borjas \& Bronars (1989) \\
\hline & & & Rees \& Shah (1986) \\
\hline \multirow[t]{5}{*}{ Female } & Lindh \& Ohlsson (1996) & & \\
\hline & Blanchflower\& Oswald(1990) & & \\
\hline & Dolton \& Makepeace (1990) & & \\
\hline & De Wit \& van Winden (1989) & & \\
\hline & Carroll \& Mosakowski (1987) & & \\
\hline
\end{tabular}

${ }^{a}:$ Effects are counted as negative or positive if the respective coefficients is different from 0 at a significance level of $p<.05$. 


\section{Table 2}

Estimates of Log-logistic Duration Model of Entry into Self-Employment

\begin{tabular}{lccc}
\hline \hline & expected sign & Coefficient & robust std. error \\
\hline HUMAN CAPITAL & & -.013 & .009 \\
IQ & & $.144^{*}$ & .062 \\
EDUCATIONAL LEVEL & - & $.506^{*}$ & .201 \\
COMMERCIAL TRAINING & & $-1.309^{* *}$ & .199 \\
SOCIAL CAPITAL & - & $-1.023^{* *}$ & .311 \\
SELF-EMPLOYED FATHER & - & $1.339^{* *}$ & .250 \\
MARRIED & + & & \\
CHILDREN & & $-.250^{*}$ & .101 \\
CONTROLS & - & $1.365^{* *}$ & .258 \\
EDUCATION FATHER & & $6.807 * *$ & .937 \\
FEMALE & & 1.059 & .073 \\
Constant & -701.85 & \\
Gamma & $102.31 * *$ & \\
log likelihood & 2966 & \\
Wald X ${ }^{2}$ & & 1339 & \\
\hline \# of records & 208 & \\
$\#$ of respondents & & \\
\# of entries & & & \\
\hline \hline
\end{tabular}

$* *: \mathrm{p} \leq .01$ and $*: \mathrm{p} \leq .05 ;$ signific ant coefficients of not supported hypotheses are printed in italics 


\section{Table 3}

Estimates of Log-logistic Duration Model of Entry into Self-Employment:

Different Education Levels

\begin{tabular}{|c|c|c|c|c|c|}
\hline & \multirow{2}{*}{$\begin{array}{c}\text { expected } \\
\text { sign }\end{array}$} & \multicolumn{2}{|c|}{ low education } & \multicolumn{2}{|c|}{ high education } \\
\hline & & coefficient & robust std. error & coefficient & robust std. error \\
\hline \multicolumn{6}{|l|}{ HUMAN CAPITAL } \\
\hline IQ & & -.018 & .014 & -.005 & .105 \\
\hline COMMERCIAL TRAINING & - & $.758 *$ & .363 & .251 & .228 \\
\hline \multicolumn{6}{|l|}{ SOCIAL CAPITAL } \\
\hline SELF-EMPLOYED FATHER & - & $-2.200 * *$ & .436 & $-.776 * *$ & .231 \\
\hline MARRIED & - & $-1.946 * *$ & .632 & -.455 & .354 \\
\hline CHILDREN & + & $1.988 * *$ & .467 & $.890 * *$ & .312 \\
\hline \multicolumn{6}{|l|}{ CONTROLS } \\
\hline EDUCATION FATHER & - & -.258 & .239 & -.156 & .106 \\
\hline FEMALE & & $1.941 * *$ & .418 & $.917 * *$ & .311 \\
\hline Constant & & $8.439 * *$ & 1.781 & $5.996 * *$ & 1.162 \\
\hline Gamma & & 1.124 & .133 & 1.020 & .090 \\
\hline log likelihood & & -285.21 & & -406.99 & \\
\hline Wald $X^{2}$ & & $78.78 * *$ & & $29.00 * *$ & \\
\hline \# of records & & 1403 & & 1563 & \\
\hline \# of respondents & & 693 & & 646 & \\
\hline \# of entries & & 93 & & 115 & \\
\hline
\end{tabular}

$* *: \mathrm{p} \leq .01$ and $*: \mathrm{p} \leq .05$; significant coefficients of not supported hypotheses are printed in italics 
Table 4

Estimates of Log-logistic Duration Model of Entry:

Different Routes into Self-Employment

\begin{tabular}{|c|c|c|c|c|c|}
\hline & \multirow{2}{*}{$\begin{array}{c}\text { expected } \\
\text { sign }\end{array}$} & \multicolumn{2}{|c|}{ real founders } & \multicolumn{2}{|c|}{ spread beds } \\
\hline & & coefficient & robust std. error & coefficient & robust std. error \\
\hline \multicolumn{6}{|l|}{ HUMAN CAPITAL } \\
\hline EDUCATIONAL LEVEL & & .042 & .066 & $.463 * *$ & .145 \\
\hline IQ & & -.006 & .010 & -.037 & .019 \\
\hline COMMERCIAL TRAINING & - & .250 & .221 & $1.214^{* *}$ & .398 \\
\hline \multicolumn{6}{|l|}{ SOCIAL CAPITAL } \\
\hline SELF-EMPLOYED FATHER & - & $-.760 * *$ & .207 & $-3.054 * *$ & .559 \\
\hline MARRIED & - & -.505 & .340 & $-2.027 * *$ & .618 \\
\hline CHILDREN & + & $.712 *$ & .280 & $3.198 * *$ & .535 \\
\hline \multicolumn{6}{|l|}{ CONTROLS } \\
\hline EDUCATION FATHER & - & $-.276 * *$ & .104 & -.149 & .227 \\
\hline FEMALE & & $1.103 * *$ & .278 & $2.078 * *$ & .530 \\
\hline Constant & & $6.712 * *$ & .991 & $10.386 * *$ & 2.247 \\
\hline Gamma & & .999 & .083 & $1.270^{\dagger}$ & .135 \\
\hline log likelihood & & -511.145 & & -276.143 & \\
\hline Wald $X^{2}$ & & $42.26 * *$ & & $71.65 * *$ & \\
\hline$\#$ of records & & 2845 & & 2689 & \\
\hline \# of respondents & & 1259 & & 1198 & \\
\hline$\#$ of entries & & 135 & & 73 & \\
\hline
\end{tabular}

$* *: p \leq .01$ and $*: p \leq .05 \dagger: p \leq .05$ (significant different from 1)

significant coefficients of not supported hypotheses are printed in italics 


\section{Figure 1}

Relation Self-Employment Rate and Relative Income Advantage of Self-Employed

The Netherlands: 1959-1993

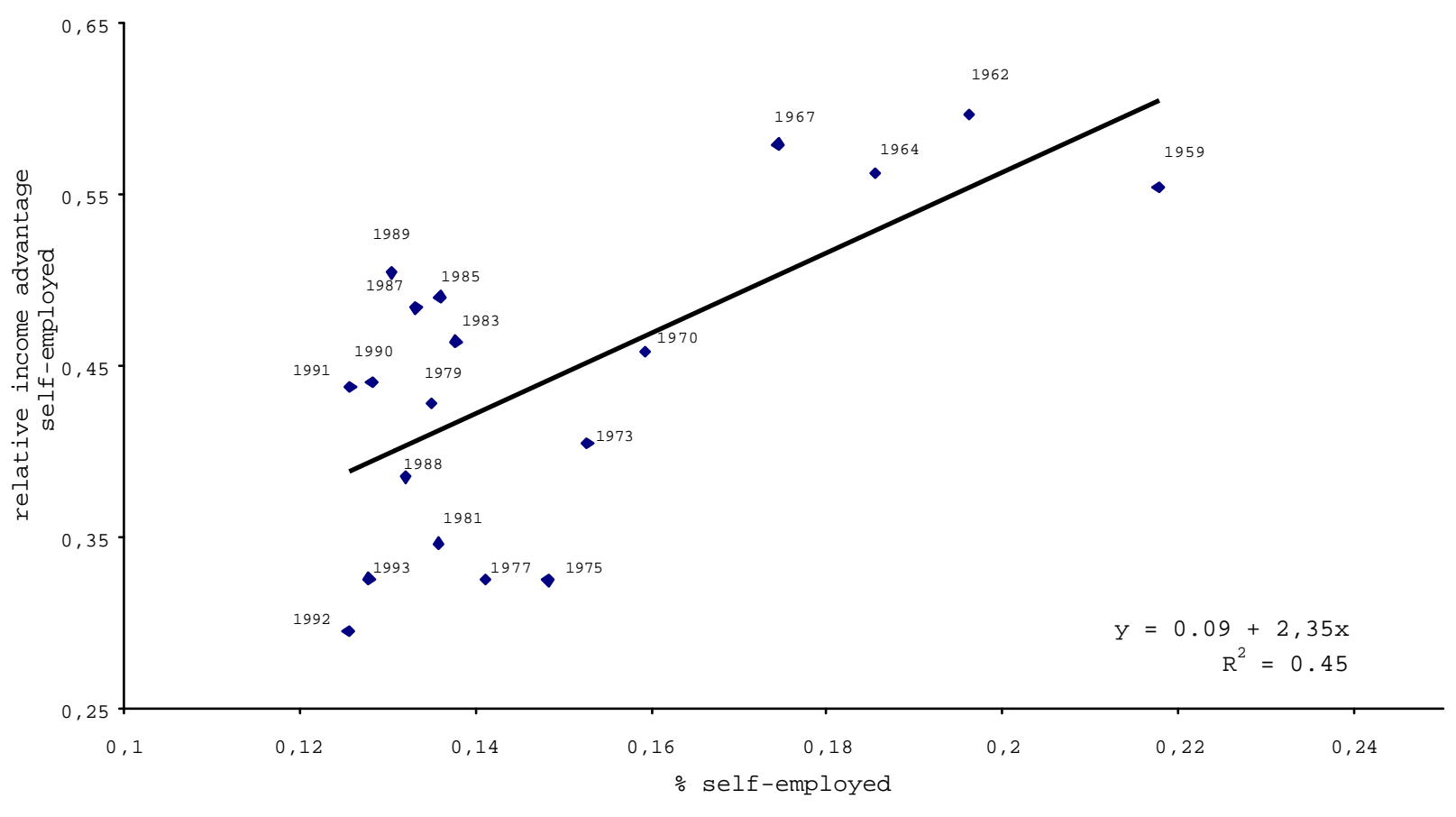


Figure 2

Structure of the Data Set

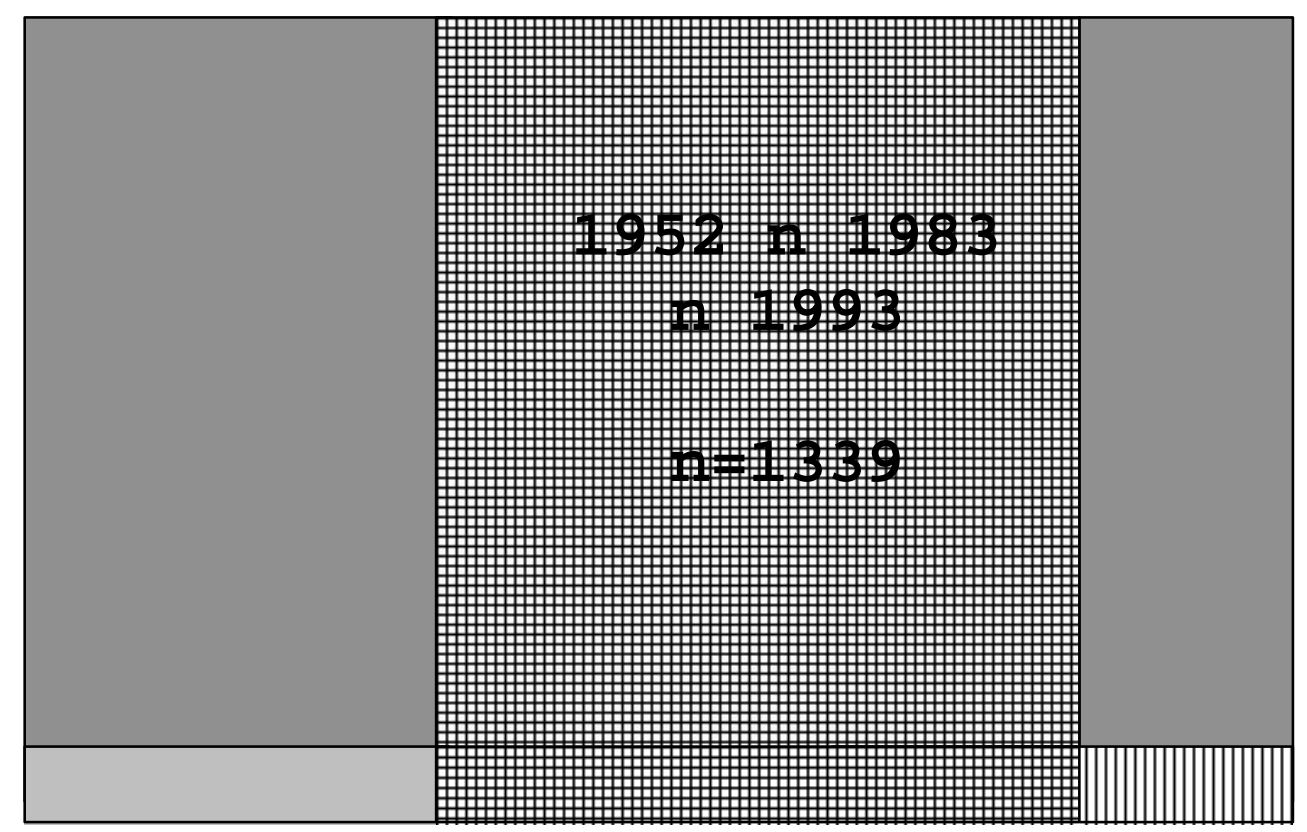

Legenda

\begin{tabular}{|l|l|l|l|l|}
\hline 1952 & & 1983 & & 1993 \\
$\mathrm{~N}=2874$ & & $\mathrm{~N}=2588$ & & $\mathrm{~N}=2099$ \\
\hline
\end{tabular}

Gray checkered area represent respondents interviewed at all three times of measurement; gray area with horizontal lines represents respondents interviewed in 1952 and 1983 and gray area with vertical lines represents respondents interviewed in 1952 and 1993. 
Figure 3

Distribution of Entry into Self-Employment

(a) total; (b) taking over a family business (spread beds); (c) founding a new company

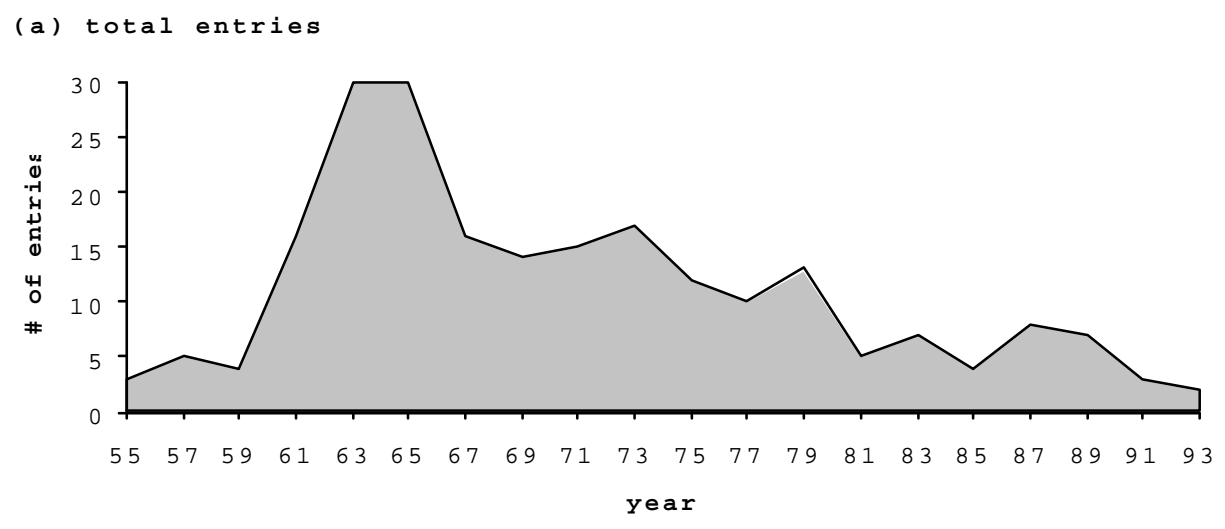

(b) spread bed

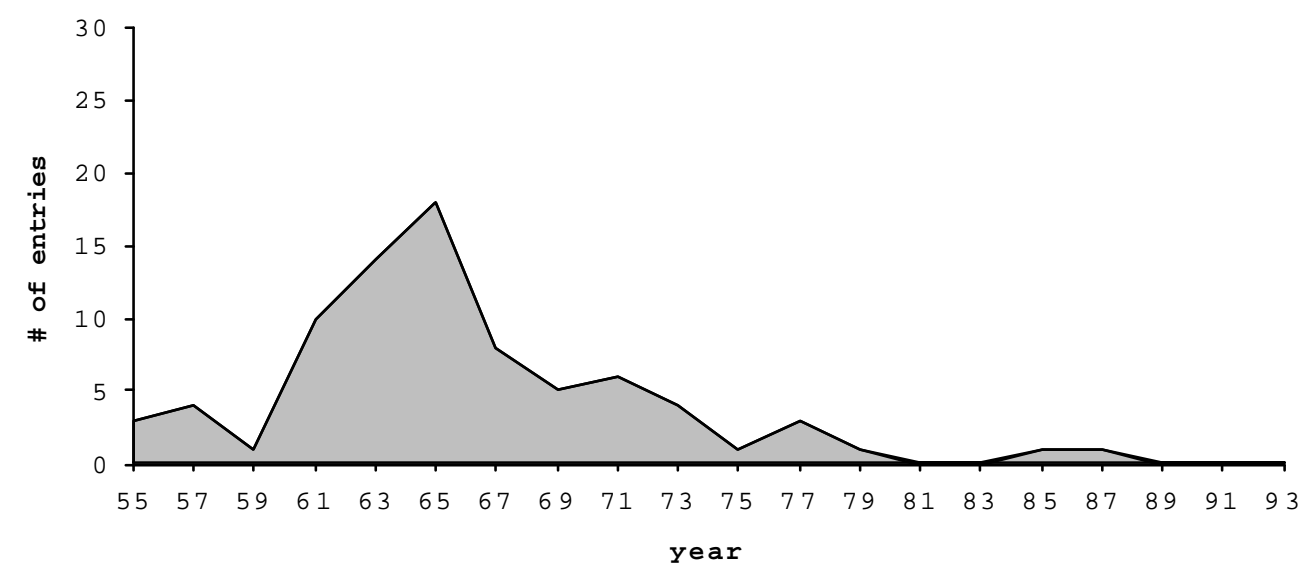

(c) real founders

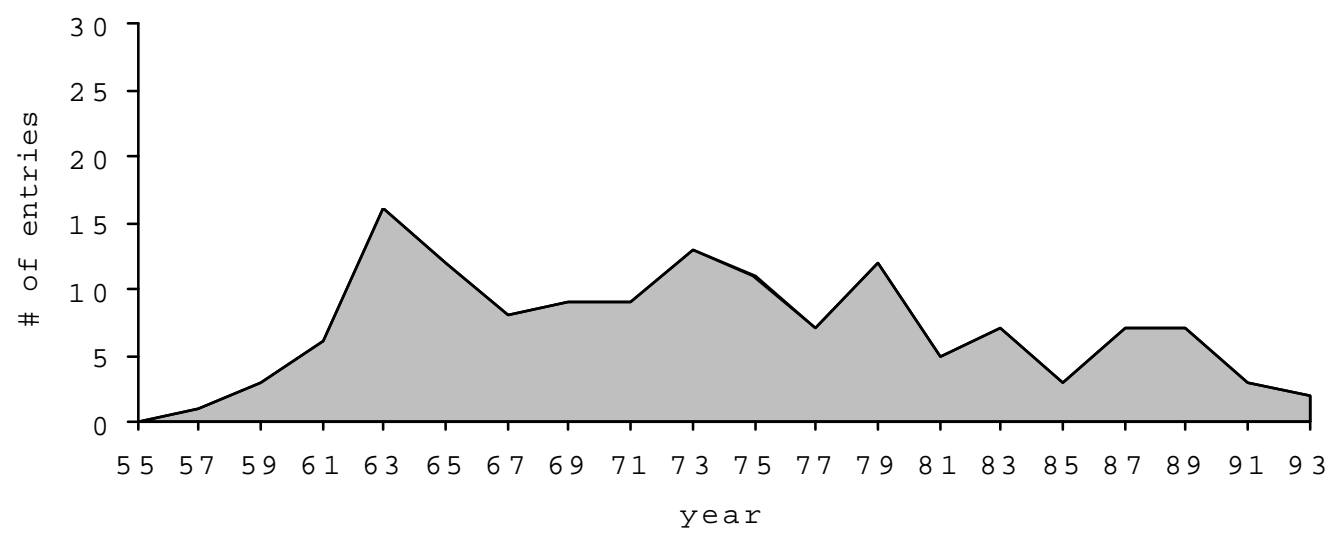




\section{Figure 4}

Graph of the Nelson-Aalen Hazard Function for the total sample and different educational levels.

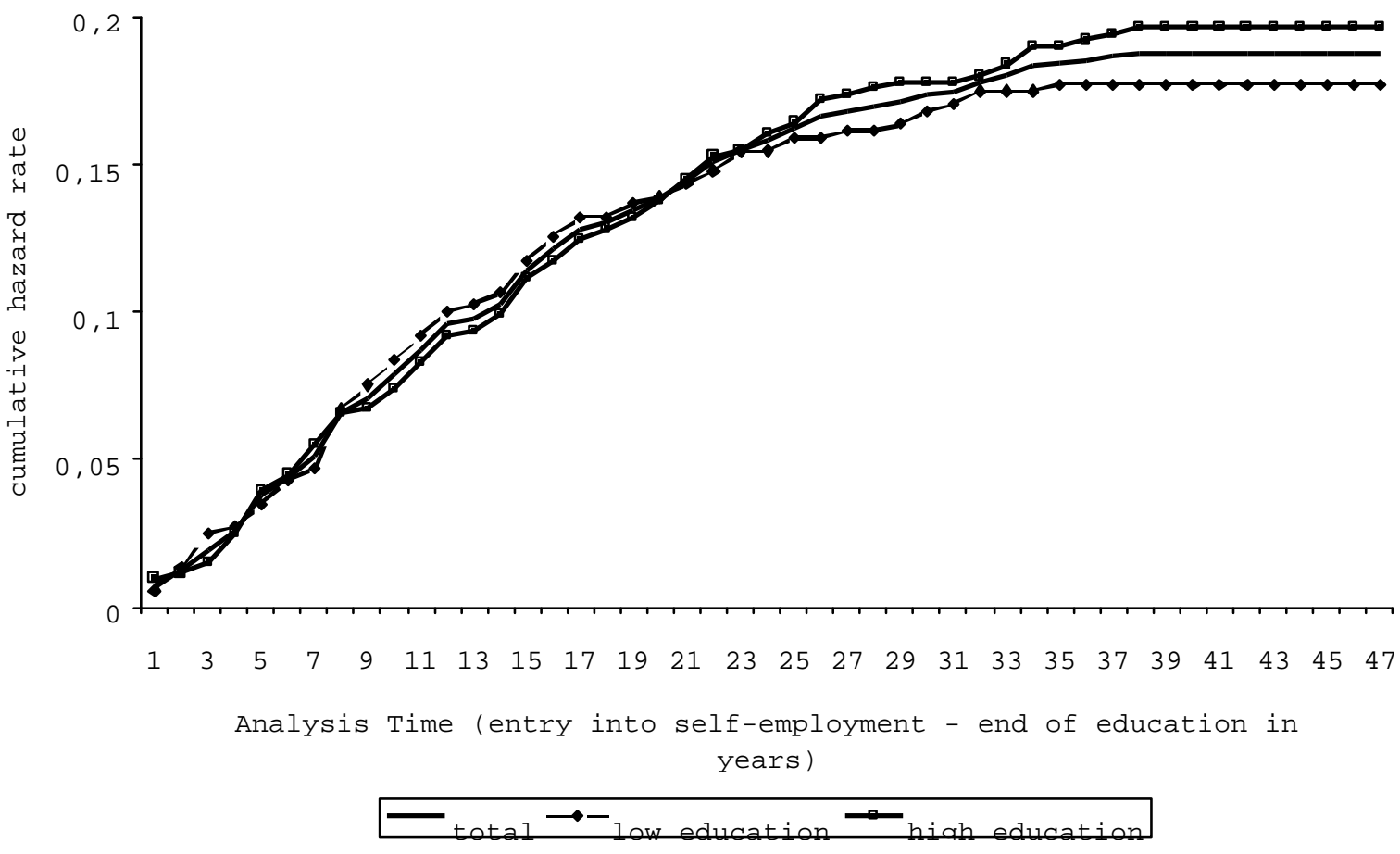




\section{Figure 5}

Nelson-Aalen Hazard Functions for Self-Employed Spread Beds and New Founders.

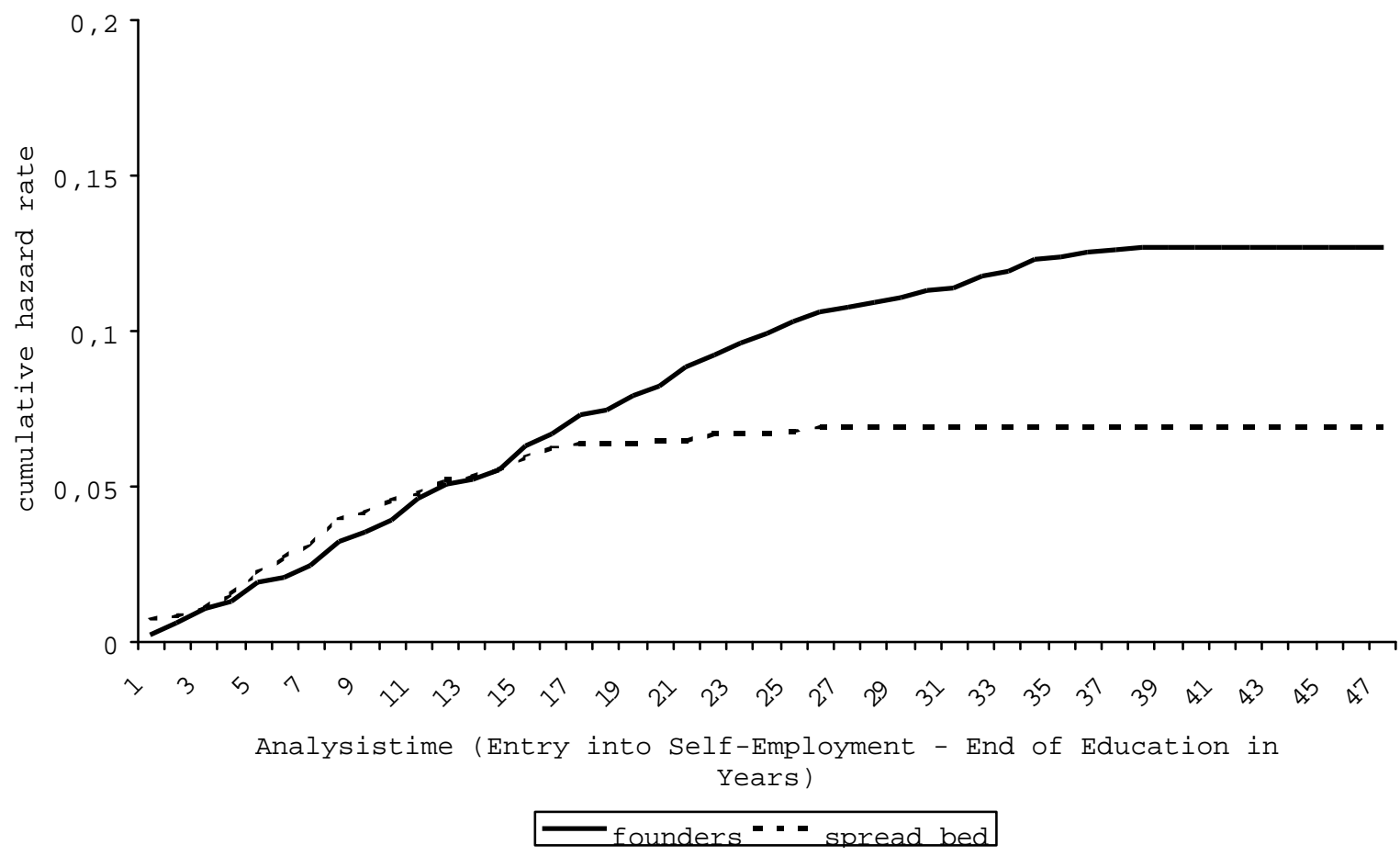




\section{Appendix 1}

Descriptive statistics of independent variables

\begin{tabular}{|c|c|c|}
\hline & mean & std. deviation \\
\hline EDUCATIONAL LEVEL & 3.60 & 1.75 \\
\hline IQ & 103.76 & 10.70 \\
\hline COMMERCIAL TRAINING & .38 & .49 \\
\hline EDUCATION FATHER & 2.50 & .84 \\
\hline SELF-EMPLOYED FATHER & .39 & .49 \\
\hline MARRIED $^{A}$ & .85 & .36 \\
\hline CHILDREN $^{\mathrm{A}}$ & .16 & .36 \\
\hline FEMALE & .35 & .48 \\
\hline
\end{tabular}




\section{IZA Discussion Papers}

\begin{tabular}{|c|c|c|c|c|}
\hline No & Author(s) & Titel & Area & Date \\
\hline 221 & C. Grund & Wages as Risk Compensation in Germany & 5 & $12 / 00$ \\
\hline 222 & W.P.M. Vijverberg & Betit: A Family That Nests Probit and Logit & 7 & $12 / 00$ \\
\hline 223 & $\begin{array}{l}\text { M. Rosholm } \\
\text { M. Svarer }\end{array}$ & $\begin{array}{l}\text { Wages, Training, and Job Turnover in a Search- } \\
\text { Matching Model }\end{array}$ & 1 & $12 / 00$ \\
\hline 224 & J. Schwarze & $\begin{array}{l}\text { Using Panel Data on Income Satisfaction to } \\
\text { Estimate the Equivalence Scale Elasticity }\end{array}$ & 3 & $12 / 00$ \\
\hline 225 & $\begin{array}{l}\text { L. Modesto } \\
\text { J. P. Thomas }\end{array}$ & $\begin{array}{l}\text { An Analysis of Labour Adjustment Costs in } \\
\text { Unionized Economies }\end{array}$ & 1 & $12 / 00$ \\
\hline 226 & P. A. Puhani & $\begin{array}{l}\text { On the Identification of Relative Wage Rigidity } \\
\text { Dynamics: A Proposal for a Methodology on } \\
\text { Cross-Section Data and Empirical Evidence for } \\
\text { Poland in Transition }\end{array}$ & $4 / 5$ & $12 / 00$ \\
\hline 227 & L. Locher & $\begin{array}{l}\text { Immigration from the Eastern Block and the } \\
\text { former Soviet Union to Israel: Who is coming } \\
\text { when? }\end{array}$ & 1 & $12 / 00$ \\
\hline 228 & $\begin{array}{l}\text { G. Brunello } \\
\text { S. Comi } \\
\text { C. Lucifora }\end{array}$ & $\begin{array}{l}\text { The College Wage Gap in } 10 \text { European } \\
\text { Countries: Evidence from Two Cohorts }\end{array}$ & 5 & $12 / 00$ \\
\hline 229 & $\begin{array}{l}\text { R. Coimbra } \\
\text { T. Lloyd-Braga } \\
\text { L. Modesto }\end{array}$ & $\begin{array}{l}\text { Unions, Increasing Returns and Endogenous } \\
\text { Fluctuations }\end{array}$ & 1 & $12 / 00$ \\
\hline 230 & L. Modesto & $\begin{array}{l}\text { Should I Stay or Should I Go? Educational } \\
\text { Choices and Earnings: An Empirical Study for } \\
\text { Portugal }\end{array}$ & 5 & $12 / 00$ \\
\hline 231 & G. Saint-Paul & The Economics of Human Cloning & 5 & $12 / 00$ \\
\hline 232 & $\begin{array}{l}\text { E. Bardasi } \\
\text { M. Francesconi }\end{array}$ & $\begin{array}{l}\text { The Effect of Non-Standard Employment on } \\
\text { Mental Health in Britain }\end{array}$ & 5 & $12 / 00$ \\
\hline 233 & $\begin{array}{l}\text { C. Dustmann } \\
\text { C. M. Schmidt }\end{array}$ & $\begin{array}{l}\text { The Wage Performance of Immigrant Women: } \\
\text { Full-Time Jobs, Part-Time Jobs, and the Role of } \\
\text { Selection }\end{array}$ & 1 & $12 / 00$ \\
\hline 234 & $\begin{array}{l}\text { R. Rotte } \\
\text { M. Steininger }\end{array}$ & $\begin{array}{l}\text { Sozioökonomische Determinanten extremistischer } \\
\text { Wahlerfolge in Deutschland: Das Beispiel der Eu- } \\
\text { ropawahlen } 1994 \text { und } 1999\end{array}$ & 3 & $12 / 00$ \\
\hline
\end{tabular}


236 R. Hujer

M. Caliendo

237 S. Klasen

I. Woolard

238 R. Euwals

A. Börsch-Supan

A. Eymann

239 F. Andersson

K. A. Konrad

240 W. Koeniger

241 W. Koeniger

242 G. Faggio

J. Konings

243

E. Brainerd

244 S. M. Fuess, Jr. M. Millea

245 F. Andersson

K. A. Konrad

246 E. Plug

W. Vijverberg

247 E. Plug

W. Vijverberg

248 P. M. Picard

E. Toulemonde

249

B. M. S. van Praag

P. Cardoso

250

T. J. Hatton

J. G. Williamson
Evaluation of Active Labour Market Policy:

6

$12 / 00$

Methodological Concepts and Empirical

Estimates

Surviving Unemployment without State Support: 3

$12 / 00$

Unemployment and Household Formation in

South Africa

The Saving Behaviour of Two Person House-

5

$12 / 00$

holds: Evidence from Dutch Panel Data

Human Capital Investment and Globalization in

Extortionary States

5

01/01

Labor and Financial Market Interactions: The

5

$01 / 01$

Case of Labor Income Risk and Car Insurance in the UK 1969-95

Trade, Labor Market Rigidities, and Government- 2 Financed Technological Change

$01 / 01$

Job Creation, Job Destruction and Employment 4

Growth in Transition Countries in the 90's

$01 / 01$

Economic Reform and Mortality in the Former

4

$01 / 01$

Soviet Union: A Study of the Suicide Epidemic in the 1990s

Pay and Productivity in a Corporatist Economy: 5

$01 / 01$

Evidence from Austria

Globalization and Human Capital Formation

5

$01 / 01$

Schooling, Family Background, and Adoption:

5

$01 / 01$

Does Family Income Matter?

Schooling, Family Background, and Adoption:

5

$01 / 01$

Is it Nature or is it Nurture?

The Impact of Labor Markets on Emergence and 2

Persistence of Regional Asymmetries

01/01

"Should I Pay for You or for Myself?"

3

01/01

The Optimal Level and Composition of

Retirement Benefit Systems

Demographic and Economic Pressure on

Emigration out of Africa 
254 H. Gersbach

A. Schniewind

255 H. Gersbach

A. Schniewind

T. Boeri

H. Brücker

257

T. Boeri

258

M. Rosholm

K. Scott

L. Husted

259

A. Ferrer-i-Carbonell

B. M.S. van Praag

260

P. Cahuc

F. Postel-Vinay

261

M. Lindahl

262

M. Lindahl

263

N. Datta Gupta

N. Smith

264

C. Dustmann

265

M. Rosholm

M. Svarer

C. Dustmann

O. Kirchkamp
Learning of General Equilibrium Effects and the Unemployment Trap

3

02/01

Product Market Reforms and Unemployment in 3 Europe

Eastern Enlargement and EU-Labour Markets: 2 Perceptions, Challenges and Opportunities

Transition with Labour Supply

4

02/01

The Times They Are A-Changin':

1

$02 / 01$

Organizational Change and Immigrant

Employment Opportunities in Scandinavia

Poverty in the Russian Federation

4

$02 / 01$

Temporary Jobs, Employment Protection and

$1 / 3$

02/01

Labor Market Performance

Home versus School Learning:

5

02/01

A New Approach to Estimating the Effect of Class Size on Achievement

Summer Learning and the Effect of Schooling:

5

02/01 Evidence from Sweden

Children and Career Interruptions:

5

02/01

The Family Gap in Denmark

Return Migration, Wage Differentials, and the

1

02/01 Optimal Migration Duration

Structurally Dependent Competing Risks

02/01

The Optimal Migration Duration and Activity Choice after Re-migration 
283 M. Hagedorn

A. Kaul

V. Reinthaler

284

H. Rapoport

A. Weiss

285

J. Jerger

C. Pohnke

A. Spermann

286 M. Fertig

C. M. Schmidt

287 P. Guggenberger

A. Kaul

M. Kolmar

288

D. A. Cobb-Clark

289

L. Cameron

D. A. Cobb-Clark

290

D. A. Cobb-Clark

M. D. Connolly

C. Worswick

291

R. T. Riphahn

292

E. Wasmer

293

D. Cobb-Clark

T. F. Crossley

294 Š. Jurajda

295
F. Duffy
P. P. Walsh

296 H. S. Nielsen

M. Rosholm

N. Smith

L. Husted
Welfare Analysis in a Schumpeterian Growth

Gut betreut in den Arbeitsmarkt?

5

04/01

Eine mikroökonometrische Evaluation der

Mannheimer Arbeitsvermittlungsagentur

First- and Second-Generation Migrants in

People Think

Efficiency Properties of Labor Taxation in a

3

04/01

Spatial Model of Restricted Labor Mobility

Getting Ahead: The Determinants of and Payoffs

5

$04 / 01$ to Internal Promotion for Young U.S. Men and Women

Old-Age Support in Developing Countries:

Labor Supply, Intergenerational Transfers and

Living Arrangements

The Job Search and Education Investments of

04/01 Immigrant Families

$05 / 01$

Cohort Effects in the Educational Attainment of Second Generation Immigrants in Germany: An Analysis of Census Data

Between-group Competition in the Labor Market and the Rising Returns to Skill: US and France 1964-2000

Gender, Comparative Advantage and Labor

05/01 Market Activity in Immigrant Families

Estimating the Effect of Unemployment

$05 / 01$ Insurance Compensation on the Labor Market Histories of Displaced Workers

Individual Pay and Outside Options:

05/01

Evidence from the Polish Labour Force Survey

4 
297 J. C. van Ours J. Veenman

298 P. Telhado Pereira P. Silva Martins

299 G. Brunello

C. Lucifora

R. Winter-Ebmer

300 A. Stutzer

R. Lalive

301 J. R. Frick

G. G. Wagner

302

G. S. Epstein

A. Weiss

303

B. F. Blumberg

G. A. Pfann
The Educational Attainment of Second Generation

1 Immigrants in The Netherlands

Returns to Education and Wage Equations

5

06/01

The Wage Expectations of European College

5

06/01 Students

The Role of Social Work Norms in Job Searching

5

06/01 and Subjective Well-Being

The Role of Social Work

Economic and Social Perspectives of Immigrant Children in Germany

06/01

A Theory of Immigration Amnesties

1

06/01

Social Capital and the Uncertainty Reduction of

5

$06 / 01$ 